logos_i_ethos_2013_2_(35), s.195-218

\title{
Mirosław Pawliszyn \\ Mikołaj Bierdiajew jako inspiracja dla filozoficznego myślenia o piekle
}

\section{Kwestie wstępne}

Problem istnienia piekła to kwestia tyleż inspirująca, co niełatwa do przeanalizowania. Jest ono rzeczywistością, o ile faktycznie jest, tajemniczą i zakrytą, a jednocześnie prowokującą do tego, by prowadzić ożywiony dyskurs. $\mathrm{Z}$ jednej strony, pobudza do refleksji, każe poszukiwać jakichś rozstrzygnięć, $\mathrm{z}$ drugiej, jawi się jako zagadnienie niepopularne, odległe od codziennych problemów, mało żywotne. Nie dość tego,

Mirosław Pawliszyn CSsR - wykłada filozofię na Uniwersytecie Warmińsko-Mazurskim w Olsztynie oraz w seminarium duchownym redemptorystów w Tuchowie. Redaktor naczelny rocznika naukowego „Studia Redemptorystowskie" oraz pisma internetowego „Człowiek-Kultura-Przyszłość". Zainteresowania naukowe: filozofia religii, metafizyka, filozofia rosyjska, filozofia śmierci. piekło przedstawia się też jako problem „aintelektualny”, a co za tym idzie, również niefilozoficzny.

U podstaw myślenia o piekle leży przekonanie o głęboko religijnym charakterze: człowiek jest istotą skłonną do grzechu (zła, w sensie moralnym) i za popełnione nieprawości spotka go w przyszłości nieunikniona kara. Kryją się za tym określone przesłanki: ludzkie uczynki mają przełożenie na wymiar wieczności, zatem ich konsekwencje nie wyczerpują się w ramach ziemskiej egzystencji. Dalej, postępki te kumulują się w jakiś bliżej nieokreślony sposób, nie są od siebie odseparowane. Złe są generalnie potępiane i analogicznie dobre są nagradzane. Wreszcie, istnieje jakaś instancja, która o popełnionych czynach „pamięta” i wyznacza konsekwencje, jakie człowiek powinien w związku z nimi ponieść.

Dla filozofii interesująca jest tak naprawdę jedna kwestia. Chodzi o pytanie: czy coś takiego jak piekło istnieje? Jakie przesłanki mogą 
przemawiać za pozytywną bądź negatywną odpowiedzią? Dopiero później wolno nam postawić pytanie: jakie jest piekło, jaką ma postać i co może się w nim wydarzyć?

\section{Krótka panorama poglądów na temat piekła}

Dla starożytnych Greków piekło jest związane ze światem mitologii, nie stanowi więc przedmiotu intelektualnych analiz. Tam, „gdzie ziemia się już kończy, gdzie nigdy nie dociera najsłabszy promień słońca - jest wejście do podziemia, czyli do piekieł”'. Motyw braku światła, przejawiający się w różnych formach, będzie odtąd nieodłączny od wyobrażeń o piekle. Ciemności piekielne będą konsekwencją złych uczynków popełnionych przez ludzi za życia ziemskiego; wątek ten rozwinie w pełni chrześcijaństwo. Istotna jest atmosfera piekła, przepełnionego dojmującym smutkiem, bezradnością, otępieniem. „W przedsionku piekielnego państwa tłoczą się dziwne i straszne postacie. Tam Smutek przechadza się w gronie swych sióstr, Trosk. Blade Choroby i wynędzniała Starość, i wiecznie dygocąca Trwoga, i obdarta Nędza snują się po wilgotnych kątach. [...] Brzydki i niechlujny dziad, zrzęda i gbur, syn Nocy, stoi w czarnej łodzi i żerdzią odpycha garnący się ku niemu tłum dusz. Wpuszcza tylko tych, którzy mają czym zapłacić. Za przewóz bierze niewiele: obola, drobny miedziany pieniążek. Ale należy go mieć przy sobie, bo Charon jest nieubłagany i gotów biedną duszę zostawić nad brzegiem Styksu, gdzie błąkać się będzie przez wieczność całą, bez celu"2. Zauważyć trzeba, że nieobecny jest tu jeszcze motyw ognia,

\section{J. Parandowski, Mitologia, Poznań 1990, s. 108.}

Tamże. Podobnie przejmujące obrazy mąk piekielnych składają się na twórczość wybitnego normandzkiego malarza Hieronima Boscha (ur. ok. 1450). Oto fragment obrazu Sąd Ostateczny. Miejsce wypełnione dymem i ogniem, wszędzie panuje mrok. Ludzie stają się obiektem zabawy dziwnych i niekształtnych istot. Można odnieść wrażenie, że jedynym celem, jaki przyświeca karykaturom zamieszkującym piekło, jest zadawanie im cierpienia. Dalej fragment obrazu Wóz $z$ sianem. Pochód w kierunku piekła rozpoczyna się w raju, w chwili, gdy kobieta wyłania się z boku Adama. Tytułowy wóz siana jest symbolem bogactwa i dostatku. Pojazdu nie ciągną zwierzęta, lecz potwory, a na plan pierwszy wysuwa się dziwna postać o kształtach człowieka i ryby. Każdy z otaczających wóz chce zdobyć dla siebie część siana, ale dzieje się to zawsze kosztem pozostałych ludzi. 
który w późniejszych wiekach stanie się dla potępionych źródłem najsroższej piekielnej męki. Przeciwnie, „królestwo cieniów to nieobeszła równina, chłodna i martwa, po której szamocą się ostre wiatry"3. Przebywanie $\mathrm{w}$ tej krainie wiąże się z wejściem w stan letargu, odrętwienia. Człowiek przestaje być w pełni sobą, zatraca świadomość, zdolność do reagowania na bodźce z otoczenia. Mamy tu do czynienia z czymś, do czego, zapewne nieświadomie, nawiąże rosyjski filozof Mikołaj Bierdiajew: z sytuacją permanentnego przebywania na granicy świadomości i otępienia, snu-majaczenia, z którego nie można się obudzić. Karą jest nie tyle ból zadawany przez złe duchy, ile męczące ,jakieś półżycie, półświadomość, półbycie" 4 .

Podobne motywy odnajdujemy w tekstach starotestamentowych. Szeol to kraina mroku. Hiob wyrazi tę prawdę słowami: „Odwróć Twój wzrok, niech trochę rozjaśnię oblicze, nim pójdę, by nigdy nie wrócić, do kraju pełnego ciemności, do ziemi czarnej jak noc, do cienia chaosu i śmierci, gdzie świecą jedynie mroki"5 (Hi 10, 20-22). Jest on stanem snu, niewiedzy, ziemią zapomnienia (por. Ps 13, 4; Hi 14, 21; Ps $88,12-13)$. „Nie ma żadnej czynności ni zrozumienia, ani poznania,

$\mathrm{Na}$ innym fragmencie człowiek-ryba, ten, który prowadził wóz, w scenie piekielnej leży bezwładny, jakby wykonał zlecone mu przez Szatana zadanie. Jednak nie jest mu dany odpoczynek. Wydaje się, że człowiek i ryba zjadają się nawzajem. Molestowani przez diabły ludzie wchodzą w ogień piekielny przez kocioł. I wreszcie trzeci, najbardziej poruszający obraz, Ogród ziemskich rozkoszy, gdzie piekło staje się sceną demonicznego przedstawienia. Widzimy torturowanych grzeszników, którzy traktowali życie jako czas rozkoszy i cielesnych uciech. Jakaś postać rozpięta na harfie, ptak zjadający i wydalający człowieka, kloaczny widok mężczyzny wydalającego złote monety. Wreszcie błazeńska postać człowieka-drzewa, który przypatruje się nam, obserwatorom sceny, ni to z ironią, ni to ze smutkiem. Jego wnętrzności to pijacy biesiadujący w karczmie, obsługiwani przez ropuchę.

Gdzie znajduje się źródło wizji artysty? Wydaje się, że ma ono charakter głęboko religijny. W centrum obrazu Siedem grzechów głównych widzimy oko Boga, a pod nim napis: „Uwaga, Bóg patrzy”. Piekło jest jakimś „efektem” boskiego patrzenia, miejscem, w którym trzeba odpokutować za popełnione winy. Człowiek w swojej grzeszności jest „nagi” przed Bogiem, nie może uciec od Jego karzącego wzroku.

J. Parandowski, Mitologia, dz. cyt., s. 109.

$4 \quad$ M. Bierdiajew, O przeznaczeniu człowieka. Zarys etyki paradoksalnej, tłum. H. Paprocki, Kęty 2006, s. 274.

Cytaty z Biblii pochodzą z: Pismo Święte Starego i Nowego Testamentu, wyd. 3. poprawione, Poznań-Warszawa 1982. 
ani mądrości w Szeolu, do którego ty zdążasz” (Koh 9, 10). Z czasem ten mitologiczny obraz Szeolu zostaje zastąpiony wizją piekła. „I staną się potem wstrętną padliną i wiecznym pośmiewiskiem wśród zmarłych. Strąci ich bowiem na głowę - oniemiałych, i wstrząśnie nimi od posad, i zostaną do szczętu zniszczeni, i będą w udręczeniu, a pamięć o nich zaginie. Z bojaźnią przyjdą zdać sprawę z win swoich, a w twarz ich oskarżą własne nieprawości” (Mdr 4, 19-20). Piekło zostaje wreszcie oddzielone od krainy tych, którzy dzięki dobrym czynom unikną kary: „Wspomnij, synu, że za życia otrzymałeś swoje dobra, a Łazarz przeciwnie, niedolę; teraz on tu doznaje pociechy, a ty męki cierpisz. A oprócz tego między nami a wami zionie ogromna przepaść, tak że nikt, choćby chciał, stąd do was przejść nie może ani stamtąd do nas się przedostać" (Łk 16, 25n). Jest ono miejscem, gdzie płonie wieczny ogień: „lepiej jest dla ciebie ułomnym wejść do życia wiecznego, niż z dwiema rękami pójść do piekła w ogień nieugaszony" (Mk 9, 43). Bóg, przychodząc na sąd, wymierza karę „tym, którzy Boga nie uznają i nie są posłuszni Ewangelii" (2 Tes 1, 8): tchórze, niewierni, obmierzli, zabójcy, rozpustnicy, guślarze, bałwochwalcy i kłamcy znajdą się w jeziorze gorejącym ogniem i siarką (por. Ap 21,8).

Podobne rozumienie piekła przez wieki ożywiało ludzką wyobraźnię. Trudno się zatem dziwić, że te obrazy i wizje nie były pociągającym tematem dla filozofii. Mimo to, przykładowo, w średniowieczu św. Tomasz z Akwinu zastanawia się, w jaki sposób dusza może odczuwać ogień piekielny, i udziela następującej odpowiedzi: „Ogień z natury swojej ma to do siebie, że niecielesny duch może się z nim połączyć, tak jak rzecz umieszczona łączy się z miejscem swojego umieszczenia. Natomiast jako narzędzie sprawiedliwości Boskiej otrzymuje dodatkową moc, dzięki której w jakiś sposób zatrzymuje go i więzi, a przez to ów ogień zadaje duszy prawdziwe cierpienie"6. Istotny w tej dyskusji jest również wkład Orygenesa, który daje impuls do odmiennego myślenia o piekle. Z całości dzieła $O$ zasadach widać jego usilne staranie o to,

6 Tomasz z Akwinu, Suma teologiczna, tłum. o. Pius Bełch, t. 33, art. III, s. 38. Cytat za: http://www.katedra.uksw.edu.pl/suma/suma_indeks.htm (19.03.2013). 
by wykazać, że męki piekielne nie są ostatecznością i że dzięki miłosierdziu Boga każdy może mieć nadzieję na zbawienie. Pisze Orygenes: „Nie można jednak mniemać, że na utopieniu skończyło się działanie opatrzności Bożej względem faraona: nie wolno nam sądzić, że utonąwszy, zginął on od razu substancjalnie"7.

Piekło, zauważmy, to z jedno z centralnych zagadnień teologicznych. Wpisuje się ono w szeroko rozumianą kwestię eschatologiczną, w pytanie o losy człowieka po jego śmierci. Polski teolog Wacław Hryniewicz myśli o piekle w kategoriach nadziei. Wprawdzie „nie wolno ignorować prawdy o piekle i potępieniu”, jednak „,kto ośmieliłby się wyrokować, że od pewnego momentu wina stworzenia nie podlega już absolutnie przeobrażającej mocy Boga i że nie może być nawiedzona? Odmowa człowieka nie da się nigdy porównać z wszechogarniającym TAK miłości Boga. Nie może ona nigdy nabrać cech absolutności. Ludzka wolność nie zdoła nigdy ograniczyć suwerenności Boga i Jego miłości”’.

Ważny dla naszych rozważań wątek wprowadza Joseph Ratzinger w pracy Śmierć i życie wieczne. Noc i mrok panujące w piekle są nieprzeniknione dla intelektu. Potrzebna jest specyficzna postawa, nastawienie ducha charakterystyczne dla kogoś, kto związany jest najgłębszą relacją z osobą Jezusa. Piekło nie jest groźbą, czymś, co straszy swoją obecnością, co czeka na mnie gdzieś, w jakimś miejscu. Można go doświadczyć w sytuacji tzw. „nocy wiary”, chwili najmocniej odczuwanej samotności, tej, którą przeżył Syn Boży, schodząc do otchłani w Wielki Piątek. Mowa tu o wewnętrznym współdzieleniu z Nim ciemności opuszczenia, której żaden intelekt nie jest w stanie prześwietlić. Jest ono tak wielkie, że człowiek staje się gotów oddać własne zbawienie na rzecz drugich ${ }^{10}$. Piekło nie jest więc jakimś miejscem w przestrzeni, ale czymś, co jest na wskroś doświadczane, staje się częścią przeżywanej egzystencji. Nie płynie stąd wniosek, że traci ono swe eschatologiczne znaczenie i może być w pełni

Orygenes, O zasadach, tłum. S. Kalinkowski, Kraków 1996, s. 241.

W. Hryniewicz, Nadzieja zbawienia dla wszystkich, Warszawa 1989, s. 165.

Tamże.

Por. J. Ratzinger, Śmierć i życie wieczne, tłum. M. Węcławski, Warszawa 1986, s. 199. 
obecne za życia. Dramat piekła dotyka, a może lepiej powiedzieć: wnika w moją własną codzienność. W tym duchu zdaje się rozprawiać o piekle Bierdiajew $^{11}$.

\section{Piekło jako problem filozoficzny}

Rosyjski filozof rozpoczyna swoje analizy od stwierdzenia: „Piekło nie jest tylko krańcowym, ale zasadniczym problemem etyki, bez rozwiązania którego etyka pozostaje powierzchowna"12. Ta powierzchowność bierze się z panującego wśród ludzi przeświadczenia, że wraz z banalizacją życia pominięta zostaje kwestia odpowiedzialności za dokonane czyny. „Współczesne negowanie piekła czyni życie zbyt łatwym, powierzchownym i nieodpowiedzialnym"13, jednak jego uporczywe przywoływanie może rodzić lęk przed możliwą karą. Lęk zaś znosi moralną wartość czynu, życie zostaje pozbawione prawdziwej wartości. Kiedy czynię coś tylko dlatego, że boję się kary za brak działania, wartość czynu zostaje podważona. Mało tego, osłabiony zostaje również religijny wymiar życia, gdyż wiara będzie motywowana strachem, a nie miłością. "Jeśli istnieje piekło i grozi mi, to bezinteresowna miłość do Boga jest dla mnie niemożliwa, to ja określam się nie przez dążenie do doskonałości, a przez dążenie do uniknięcia mąk piekielnych"14.

Ta swoista antynomia sprawia, że interesujący nas problem nabiera szczególnego znaczenia. Z jednej strony niebezpieczna tendencja do banalizowania życia, z drugiej możliwość ograbienia go z tego, co stanowi o samej istocie człowieka. To właśnie dlatego zagadnienie piekła domaga się rozpatrzenia i przeanalizowania. Będzie to próba ocalenia człowieka w obliczu dwóch niszczących go perspektyw. Pierwsza z nich nie domaga się specjalnej refleksji, gdyż banał zawsze jest czymś, co stępia wrażliwość, i dotyczy to bodaj każdej sfery życia. Druga jest znacznie

11 Zgodnie z tytułem poglądy Mikołaja Bierdiajewa mają być inspiracją do rozważań na temat piekła. Autor nie ogranicza się zatem do czystego zreferowania jego poglądów.

12 M. Bierdiajew, O przeznaczeniu..., dz. cyt., s. 269.

13 Tamże.

14 Tamże. 
bardziej frapująca - okazuje się, że możliwe jest zniszczenie wolności w imię moralności i religijności, w imię posłuszeństwa.

Skoro kwestia piekła jest jednym z centralnych problemów etyki, to musi być ono nierozerwalnie związane z człowiekiem. Innymi słowy, piekło to sprawa człowieka. Jest dane niejako dla niego, jako możliwość, angażująca wszystkie istotne wymiary jego egzystencji ${ }^{15}$.

Pośród różnych wymiarów życia możemy odnaleźć te, które wydają się związane z ideą piekła, sugerując, czym mogłoby ono być. Dla przykładu, należy tu wymienić chociażby doświadczenie samotności, która staje się zapowiedzią absolutnej pustki piekielnej. Wspomnieć wolno o przeżyciu dogłębnego smutku, wywołanego przez nieprzezwyciężalne (przynajmniej subiektywnie) przeszkody stawiane przez los, co zakłada wiecznie przeżywaną i niepokonalną rozpacz. Bierdiajew wspomina też o innym wymiarze, poprzez który ujawnia się „ciemna” strona ludzkiego ducha. Jest nim pragnienie zemsty, odwetu. Ci, którzy uważają siebie za dobrych, domagają się zemsty na tych, którzy w ich mniemaniu czynią ewidentne zło. Dobro i zło są w stanie permanentnej walki, a kara dla złych jest czymś absolutnie zasłużonym, wręcz niezbędnym. Przemawia za tym elementarne poczucie sprawiedliwości. To manichejskie myślenie, jak zauważa po wielekroć Bierdiajew, nieobce chrześcijaństwu, domaga się z konieczności istnienia piekła jako miejsca zapłaty za popełnione grzechy ${ }^{16}$.

Rozważania o piekle można prowadzić na dwa sposoby, patrząc na nie od strony Boga i od strony człowieka. Pierwsza możliwość zakłada, że twórcą piekła jest Bóg. Ma ono wówczas charakter obiektywny, jest jakimś miejscem, czymś, co da się jakoś wyodrębnić od reszty. Jest w z ás wiata ch, we władaniu złego ducha, Szatana. Wynikają z tego daleko idące reperkusje. Wymieńmy je za Bierdiajewem. Jeśli piekło ma charakter obiektywny, to musimy przyjąć, że Bóg, stwarzając świat

15 Nie mówimy nigdy o piekle, które możliwe jest dla roślin czy zwierząt. Nawet jeśli jesteśmy skłonni mniemać, że zwierzęta, szczególnie te bliskie nam, trwają w jakiejś formie po śmierci, to zawsze myślimy o tym w sensie pozytywnym. Nikomu nie przychodzi do głowy myśl, że choćby najbardziej krwiożercze zwierzęta mają swoje piekło.

16 Por. tamże, s. 274-275. 
i człowieka, przewidział również zaistnienie miejsca potępienia ${ }^{17}$. Ustanowił On tym samym pewien obszar poza swoją jurysdykcją, terytorium, nad którym nie będzie miał pełni władzy. Choć brzmi to kontrowersyjnie, można to porównać z zachowaniem malarza, który tworzy dzieło sztuki i jednocześnie śmietnik, gdzie będzie można wyrzucić efekt jego pracy. Wydaje się, że mamy tu do czynienia $z$ działaniem niezrozumiałym i nielogicznym. Mało tego, rodzi się pytanie: jak mają się do siebie teoria o stworzeniu człowieka $\mathrm{z}$ miłości z równoczesnym powstaniem miejsca przeznaczonego na jego ostateczną zagładę? Możliwe, że piekło to efekt buntu aniołów, ale wówczas Szatan staje się konstruktorem rywalizującym z Bogiem. Posiada on moc budowania miejsca będącego ostatecznym przeznaczeniem człowieka, i to takiego, do którego Bóg nie ma żadnego dostępu. Słusznie zauważa rosyjski filozof, że w konsekwencji taki Bóg ponosi fiasko w starciu z Szatanem. Istota boska jest więc albo okrutna, albo bezradna. Zacytujmy: „Bóg świadomie dopuszczający wieczne męki piekielne wcale nie jest Bogiem, podobny jest on raczej do diabła"18.

Problemy wiążą się nie tylko z perspektywą stworzenia. Rodzi się pytanie: jak Bóg znosi fakt, iż jest bodaj jedna istota, która przebywa w piekle? Czy Bóg „ścierpi piekło jako odrębny krąg diabelskiego bytu obok Królestwa Bożego"19? Pytania te, jakże trafnie, rozwija współczesny teolog niemiecki Hans Küng. Czy Bóg miłości wraz z tymi, którzy są zbawieni, mogą przypatrywać się katuszom, jakie znoszą inne stworzenia? Czy męki te są potrzebne Bogu, by mógł odzyskać honor utracony na skutek ludzkiego grzechu? I jeszcze dobitniej: Bóg miłosierdzia okazuje je tylko niektórym; Bóg pokoju utrwala niezgodę na całą wieczność; Bóg nawołujący do miłowania nieprzyjaciół mści się na swoich nieprzyjaciołach? Gdybyśmy w miejsce Boga postawili człowieka, jak osądzilibyśmy jego tak nienasycone poczucie zemsty? ${ }^{20}$ Jeśli przyjąć, że

Por. tamże, s. 271.

Tamże.

Tamże.

Por. H. Küng, Życie wieczne?, tłum. Z. Mikołejko, Kraków 1993, s. 206-208. 
piekło faktycznie istnieje, konsekwencja może być tylko jedna: „Wieczne piekło byłoby równocześnie piekłem dla Boga, piekłem jego boskiej miłości, okrutnym potępieniem samego siebie"21.

Bierdiajew odrzuca zdecydowanie możliwość utworzenia ontologii piekła. Równie nietrafne jest mówienie o nim jako o miejscu, gdzie demony męczą grzeszników, jak i traktowanie go w kategoriach bezgranicznej i niemożliwej do pokonania rozpaczy, w której pogrążony jest każdy przebywający w nim. Inaczej ma się rzecz, kiedy spoglądamy na omawiany problem od strony subiektywnej. $\mathrm{Z}$ tego punktu widzenia „piekło staje się zrozumiałe, jest ono dane w ludzkim doświadczeniu"22. Pojawia się jako konieczny warunek doświadczenia egzystencji. Jest tak samo nieuchronne (nie w tym sensie, że jestem nań skazany), jak sam fakt śmierci.

\section{Piekło i idea sprawiedliwości}

Zobiektywizowane piekło, jak już wyżej zauważyliśmy, jest owocem pragnienia sprawiedliwości, odpłatą za popełnione przez człowieka złe czyny. Można powiedzieć: ile winy, tyle kary, ile uczynionego za życia zła, tyle stosownej męki. W piekle dokonuje się precyzyjne i konsekwentne rozliczenie życia. Bierdiajew analizuje tę kwestię szczegółowo.

Punktem wyjścia staje się rozróżnienie pomiędzy złem a grzechem. Wedle tradycyjnej teologii zło jest brakiem dobra, które rzecz z natury powinna posiadać. Zło nie jest czymś, nie przybiera żadnej formy. Zatem, chcąc być konsekwentnym, należy mówić raczej o grzechu, a nie o złu. Grzech bowiem jest jakoś zauważalny, uchwytny, policzalny. Jednak z drugiej strony, trudno jest wymazać ze świadomości poczucie zła, ono „nie tylko jest, ale przeważa w świecie”23. Pojawia się więc pokusa, by problem zła pominąć, pozostawić poza obszarem refleksji. Bierdiajew

21 W. Hryniewicz, Nadzieja zbawienia dla wszystkich, dz. cyt., s. 103.

22 M. Bierdiajew, O przeznaczeniu..., dz. cyt., s. 271.

23 Tenże, Egzystencjalna dialektyka Boga i człowieka, tłum. H. Paprocki, Kęty 2004, s. 64. 
będzie mówił o chęci ucieczki „W sferę neutralną”" Jak to rozumieć? Ucieczka w neutralność dokonuje się w momencie, kiedy uświadamiam sobie, że funkcjonuję w świecie jako indywiduum podległe cierpieniu i wpływom zła. Życie jednostki jest słabe, pogrążone w niemocy. Jednak to właśnie indywiduum jest elementem większej całości, gatunku, który jawi się jako bardziej odporny na zło i obojętny wobec jego siły. „Geniusz gatunku jest chytry i zawsze podpowiada nieszczęsnemu człowiekowi fałszywe usprawiedliwienia, przez które trzyma go w niewoli. $\mathrm{Z}$ tego powodu życie historyczne i społeczne jest budowane na fałszu. Fałsz może być formą oszukiwania samego siebie, kiedy człowiek staje się igraszką społecznych i gatunkowych sił życia”25. Właśnie w tym, co neutralne i powierzchowne, a co za tym idzie, również fałszywe, „mieszka” diabeł. Tak „dokonuje się obiektywizacja wewnętrznego dramatu duszy człowieka”26. Jest to rodzaj ucieczki od samego siebie w kierunku grupy, społeczności, w której się żyje, próba samousprawiedliwienia za obecne zło. W akcie oddania się jednostki na rzecz zbiorowości diabeł stał się kimś silnym, „zadomowionym”, obecnym w świecie.

Jak zauważa dalej Bierdiajew, „idea diabła była nadużywana, straszono nią ludzi i rozbudowywano królestwo diabła do ogromnych rozmiarów, dołączano do niego coraz to nowe dziedziny. W ten sposób stworzono autentyczny terror duchowy" ${ }^{27}$, który stał się zalążkiem naszego myślenia o piekle. Jesteśmy przekonani, że z demonem trzeba walczyć, pokonać go. Problem polega jednak na tym, że w walce tej ukryta jest pułapka. Jak trafnie zauważa rosyjski filozof: „Walka ze złem łatwo nabiera charakteru zła, zaraża się złem"28. Opiszmy ten schemat. Dobry (lub ten, kto się za takiego uważa) w imię dobra podejmuje walkę ze złem, stara się je zneutralizować i unieszkodliwić. Może jednak zdarzyć się sytuacja, że batalia ta prowadzona jest przy użyciu niewłaściwych środków, przybierając karykaturalne czy ekstremalne formy. Chęć

\footnotetext{
24 Tamże.

25 Tamże, s. 65.

26 Tamże, s. 64.

27 Tamże.

28 Tamże, s. 65.
} 
pokonania niegodziwości w imię dobra sama w sobie staje się czymś z gruntu złym. Dobro zatem zamienia się w zło, staje się swoim własnym zaprzeczeniem. Przychodzi moment, kiedy dobry (już zły) przestaje wierzyć w jakiekolwiek inne metody walki prócz tych, które podejmuje. Pisze Bierdiajew: „Głównym problemem moralnym naszych czasów jest problem stosunku do wroga. Wroga przestaje się uważać za człowieka, w stosunku do niego nie może być ludzkiej relacji. W tym punkcie nastąpiło największe odejście od prawdy Ewangelii. Nie sądzę, żeby istniały beznadziejnie demoniczne natury, to znaczy takie natury, nad którymi ciąży fatum opętania przez demony, podobnie jak nie sądzę, żeby istniały demoniczne narody. Istnieje jedynie demoniczny stan ludzi i narodów”29. Wróg z definicji jest zły, nie ma czegoś (kogoś) takiego jak „dobry wróg”. Jest on kimś, kto ponosi winę za mój wewnętrzny dyskomfort spowodowany jego obecnością, a nawet za to, że musiałem w ogóle podjąć walkę. Ostatecznie ponosi również winę z tego powodu, że się pojawił, że zaistniał w polu mojej świadomości. Bierdiajew dodaje jeszcze jeden element: wróg staje się, paradoksalnie, kimś absolutnie koniecznym dla mojego funkcjonowania. Jeśli zabraknie wrogów prawdziwych, zaczyna się proces ich wymyślania, konstruowania ${ }^{30}$.

Dochodzimy do zasadniczego punktu, który uruchamia nasze myślenie o piekle. „Zobiektywizowana zostaje zła potrzeba doświadczania radości okrucieństwa, kolektywnego zadowolenia z zadawania bólu, z prawa karania i bycia obecnym przy wymierzaniu kary" ${ }^{31}$. Innymi słowy, zły zasługuje na karę dlatego, że sprzeciwia się ustalonemu porządkowi rzeczy. Choć Bierdiajew nie mówi tego wprost, trzeba jeszcze coś dopowiedzieć. Otóż moje przekonanie, iż zły zasługuje na karę, zostaje dodatkowo podbudowane. Ostatecznie zło zostało wyrządzone nie tylko mnie. Jest jeszcze ktoś, kto ustalił odwieczne prawa, i to on został wzgardzony. Porządek pochodzi od Boga, którego ja, dobry, słucham. 
Zły występuje przeciw boskiej istocie i de facto to ona wymierza grzesznikowi absolutnie zasłużoną, dodajmy - piekielną, karę.

Należy podkreślić, że w rozumowaniu tym ujawnia się istotny wątek. Piekło nie tyle zostaje ustanowione przez jakąs istotę „ponadludzką" (Boga czy złego ducha), ile jest raczej wytworem woli człowieka, która dzieli świat na obozy, królestwo dobrych i złych, posłusznych i nieposłusznych woli boskiej. Dobrzy są spadkobiercami, dobrymi synami, zasługującymi na niebo, źli to odstępcy, którzy powinni ponieść zasłużoną karę.

Problem jednak pogłębia się. Ludzie żyjący w sposób zgodny z postanowieniami Boga są szczęśliwi, ponieważ spełniają dobre uczynki. Wystawieni są jednak na działanie dotkliwej pokusy. Grozi im ona wówczas, gdy ogarnie ich tzw. „święte oburzenie”; uświadomią sobie, że obok nich są tacy, którzy postępują inaczej niż oni. Owo „inaczej” znaczy tyle, iż żyją oni niezgodnie z wolą Stwórcy. Gniew i zgorszenie spowodowane czynami złych wprowadzają niepokonalny podział; „między nami a wami zionie ogromna przepaść, tak że nikt, choćby chciał, stąd do was przejść nie może ani stamtąd do nas się przedostać" (Łk 16, 26). W ten sposób wypełnia się sprawiedliwość. Odizolowani definitywnie od dobrych źli już nigdy nie wyrządzą im krzywdy, nie staną na ich drodze, nie będą oburzać nie tylko popełnianymi czynami, ale również swoją obecnością. Dobrzy nie są już tylko usatysfakcjonowani tym, że zło zostało pokonane; są ostatecznie pocieszeni ${ }^{32}$.

\section{Piekło zobiektywizowane}

Przytoczone opisy, choć momentami nieco uproszczone, trafnie oddają mechanizmy ludzkiego myślenia o piekle. Pokazują, że u jego podstaw tkwią przeświadczenia o charakterze emocjonalno-psychicznym. Skoro wiemy już, że jednostka istnieje w społeczności, jest składową gatunku, to nie może być niezależna od niego. Jest indywiduum i to, co uniwersalne, człowiek i zbiorowość, w której on żyje. Jak już wiemy, gatunek ma to do siebie, że więzi jednostkę, nie pozwala jej uwolnić się

32 Por. M. Bierdiajew, O przeznaczeniu..., dz. cyt., s. 278. 
spod swojego wpływu. Bierdiajew rozwija swoją koncepcję, twierdząc, że społeczność uprzedmiotawia piekło.

Jak powie rosyjski filozof, usprawiedliwianie piekła, poprzez opisaną wyżej ideę sprawiedliwości, jest „najbardziej oburzające i najmniej pogłębione"33. Uprzedmiotowienie ujawnia się na dwóch płaszczyznach: eschatologicznej, która rozpada się na „indywidualno-osobową i uniwersalno-historyczną" ${ }^{34}$, oraz związanej z rozumieniem czasu.

Perspektywa eschatologiczna wiąże się z momentem śmierci konkretnego człowieka - z moją własną śmiercią. Jednak, co należy podkreślić, jest też drugi ważny element eschatologii. Odnosi się on do końca historii, kiedy ma nastąpić ostateczne osądzenie ludzkości. Pomiędzy tymi dwoma wydarzeniami rozciąga się jakaś rzeczywistość trudna do uchwycenia i scharakteryzowania. Jest to stan niejasnego oczekiwania, albo inaczej - trwania przepełnionego nadzieją. Bierdiajew będzie mówił o „pustym czasie” ${ }^{35}$. Nie oznacza to jednak, że przeżywam go sam. Los powszechny, ogólnoludzki, jest wciąż moim udziałem i pozostaję weń zaangażowany. Niepowodzenie ogółu będzie moją osobistą porażką, i odwrotnie. Płynie stąd ważny wniosek: mój własny los oraz los całej rzeczywistości są ze sobą ściśle powiązane.

Potępianie w imię sprawiedliwości niweczy ów stan wzajemnej odpowiedzialności. W zamian mamy do czynienia z totalną porażką człowieka, świata i Boga. Uprzedmiotowienie piekła jest degradacją czasu, unicestwieniem wszelkiej twórczości, aktywności życiowej. „Autorytarny system podporządkowania powstał pod wpływem afektu lęku przed zgubą, panicznego lęku przed wiecznymi mękami w piekle. $\mathrm{Z}$ takimi nastrojami duchowymi, $\mathrm{z}$ takim stanem świadomości, bardzo trudno jest osiągnąć twórczy stosunek do życia. Gdzie tu może być miejsce na twórczość, gdy zagraża zguba?" ${ }^{36}$ W zamian doświadcza

\footnotetext{
33 Tamże, s. 269.

34 M. Bierdiajew, Zarys metafizyki eschatologicznej, tłum. W. i R. Paradowscy, Kęty 2004, s. 158.

35 Tamże.

36 M. Bierdiajew, Głoszę wolność, tłum. H. Paprocki, Warszawa 1999, s. 74.
} 
się czegoś, co Bierdiajew nazwie „pustym”37 albo „zdegenerowanym” 38 czasem, który skazuje człowieka na odizolowanie od „historii, losów świata i ludzkości” ${ }^{39}$. To zaś sprawia, że nie wychodzi on ku wieczności, którą należy przeżywać w duchu jedności z tym, co go otacza.

Jak ma się omawiane zagadnienie do problematyki czasu? Wspomniano już, że przyjęcie istnienia piekła jako miejsca wiecznej kaźni w rzeczywistości oznacza porażkę Boga. Wówczas ostateczny tryumf należy do diabła, skoro na wieki staje się on panem jakiejś części ludzkich dusz, mając nad nimi władzę na podobieństwo boskiej istoty. Cała historia, wszystko, co dzieje się w świecie, naznaczone jest perspektywą realnej i ostatecznej przegranej. Spójrzmy na ten problem od strony człowieka.

Jest on istotą wielorako ograniczoną, która chce ten fakt przezwyciężyć poprzez wiarę we własną nieśmiertelność. Obrazy raju czy piekła są próbą poradzenia sobie $z$ niedostatkami własnej egzystencji. Jest w nich zawarte pragnienie otrzymania zapłaty za spełniane w życiu dobro (niebo dla mnie) oraz zadośćuczynienia za doznane niepowodzenia (piekło dla innych).

Powróćmy do wątku poruszonego wyżej. Walka za złem może sprawić, że ten, kto ją podejmuje, zaczyna stosować niewłaściwe środki. Jego wysiłek skupia się na tym, by grzesznik został unicestwiony poprzez działanie „mściwych i okrutnych instynktów”40. Te zaś tworzą okrutną eschatologię, od której „nie jest również wolna Apokalipsa chrześcijańska" ${ }^{11}$. Podjęta batalia sprawia, że ktoś taki zamyka się w sobie, ogranicza samego siebie. W człowieku zostaje zabita moc twórcza. Jest to coś w rodzaju zwinięcia się w sobie, niemożności nadążenia za samym sobą, odgrodzenia się od własnej, z natury dobrej, istoty. Powie Bierdiajew: „Człowiek jest istotą zdolną przekraczać siebie samego i to właśnie transcendowanie siebie, wyjście poza zamknięte granice,

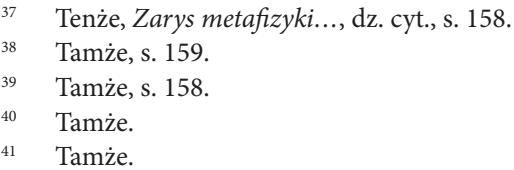


jest twórczym aktem człowieka" ${ }^{42}$. Tymczasem w procesie, o którym mowa, „wieczność zamyka się i pozostaje tylko niedobra nieskończoność" 43 . Ten stan zamknięcia daje człowiekowi możliwość pełnego doświadczenia piekła. Będzie ono przeżywane „W zamkniętej sferze subiektywnej” ${ }^{44}$, jego "przestrzenią” staje się odgrodzona od świata osoba. Jedynym mieszkańcem takiego piekła jest ten właśnie człowiek, a jego męką doświadczana przezeń samotność. Bierdiajew rozwija tę myśl. Udręka pozostawania ze sobą zdaje się mieć charakter nieskończony; choć umieszczona jest w czasie, to pozbawiona kresu. „Tylko takie męki wydają się nam piekielne i straszne, które dano nam nie na minutę, nie na godzinę lub dzień, a na nieskończoność" ${ }^{45}$. Mamy więc do czynienia $\mathrm{z}$ sytuacją zamknięcia się w przeżyciu własnego udręczenia, a ma ono taką moc, że wyjście poza siebie, przekroczenie ograniczeń, próba spojrzenia z dystansu wydają się całkowicie nieosiągalne.

Dochodzimy do zasadniczej myśli, którą chce uwyraźnić rosyjski filozof. Piekło znajduje się właśnie w owym z a mkn i ęci u s ię w sobie. Nie ma ono obiektywnego charakteru, nie jest czymś, nie jest gdzieś, nie jest miejscem przebywania tych, którzy za życia czynili zło. „Piekła nigdzie nie ma, poza widmową, niebytową, właśnie pozbawioną wszelkiej obiektywności sferą zamkniętości subiektu w samym sobie, bezsilnego, aby wejść do wieczności. Piekło wcale nie jest wiecznością, piekło jest nieskończonym przedłużaniem w czasie" ${ }^{\prime 4}$. Jest ono zatem na wskroś czasowe, przeżywane wewnątrz narastającej subiektywności, w dotkliwym przebywaniu sam na sam $z$ własnym cierpieniem. W tym sensie piekło nie jest bytem, czymś, co można zlokalizować i opisać. Ma charakter widmowy, jest tylko pozorem, cieniem. Stwarza złudzenie własnej realności, wywołuje lęk, wytrąca $z$ równowagi. Jest więc i zarazem go nie ma, niby daje się scharakteryzować, ale charakterystyka ta jest nieoczywista. Właściwie jedyną funkcją, jaką widmo ma do spełnienia, jest wywołanie w człowieku

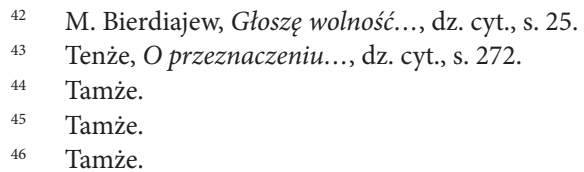


nieprzezwyciężalnej (przynajmniej subiektywnie) grozy. Jednak dla tego, kto jej doświadcza, ma ona charakter obiektywny, jest „największą psychologiczną, subiektywną realnością" ${ }^{47}$, podobnie jak sen. Każdy wie, że sny są fikcją, jednak w chwili, kiedy są śnione, jawią się jako autentyczne i prawdziwe. W piekle więc „przędziona jest widmowa tkanina koszmarów i snów; z których człowiek nie może obudzić się w wieczności, ale które właśnie dlatego nie mogą być wiecznymi”"48.

\section{Piekło i idea wolności}

Piekło jest dla żyjącego człowieka szczególnym rodzajem doświadczenia. Jego widmowy charakter każe myśleć o nim jako o niebycie. Istotna jest tu jedna wskazówka. Przeżycie piekła możliwe jest o tyle, o ile w osobie „nie pociemniał ostatecznie obraz Boży, o ile światło Boże rozjaśnia jeszcze ciemności złych fantasmagorii”"49. Zauważmy doniosłość tych słów. Piekło to nie stan zapomnienia o Bogu, przeciwnie, Jego wspomnienie, pamięć o Jego obecności są żywe. Niebyt ma więc charakter pozorny, mamy tu raczej do czynienia z przebywaniem w jakimś półświecie, w którym realność to brak czegoś, co było doświadczane. Brak ten jest źródłem przeżywanego bólu. Chwila, w której człowiek ostatecznie utraci pamięć o Bogu, będzie równoznaczna z pogrążeniem się w nicości. „Jeśli wyobrazić sobie, że obraz i podobieństwo Boże ostatecznie pociemnieją i światło Boże zupełnie przestanie świecić, to męki piekielne ustaną, to nastąpi ostateczny powrót do niebytu. Ostateczna zguba jest do pomyślenia jedynie jako niebyt, nieznający już męki” ${ }^{50}$. Co wprowadza człowieka w stan umęczenia samego siebie? Bierdiajew ma jasną odpowiedź: irracjonalna wolność.

Dotykamy kwestii, która od wieków nurtuje myśl ludzką. Jest to pytanie o wolność jako taką. Nie chodzi jednak o jej naturę, na plan pierwszy

\footnotetext{
47 Tamże.

48 Tamże.

49 Tamże, s. 273.

50 Tamże.
} 
nie wysuwa się zagadnienie możliwości wyboru pomiędzy różnymi rozwiązaniami. Pytamy: jak ma się ludzka wolność do boskiej wszechwiedzy? Konsekwencje odpowiedzi są doniosłe. Bóg, aby był prawdziwie Bogiem, musi wiedzieć wszystko o wszystkim, co kiedykolwiek może się wydarzyć. Nie ma takiego stanu, w którym byłby On pozbawiony tej pełni wiedzy, ani chwili, kiedy zostałby ubogacony o coś, czego do tej pory nie wiedział. Stworzenie człowieka uwzględnia ową wszechwiedzę. Zatem Bóg, wyposażając człowieka w rozmaite dyspozycje, nade wszystko w umiejętność wybierania, musiał wiedzieć, jakie będą tego konsekwencje. Wolność wszak została powiązana z odpowiedzialnością, każdy wybór ma od tej pory swoje reperkusje. Można zapytać: dlaczego człowiek otrzymał możliwość, która może go oddzielić ostatecznie od Tego, który mu ją podarował? Innymi słowy: czemu człowiek stał się istotą wolną, skoro w wolny sposób może odwrócić się od dawcy wolności? Mało tego, skoro Bóg jest wszechwiedzący, znaczy to, że od samego początku wie, kto z ludzi i w jaki sposób wykorzysta otrzymaną wolność. Dotykamy tu problemu, który porusza św. Augustyna, Orygenesa, Kalwina, czy wreszcie, w naszych czasach, Leszka Kołakowskiego. Konsekwentne pojmowanie boskiej wiedzy doprowadzi nas nieuchronnie do pytania o predestynację.

Bierdiajew powie: „Piekło jest irracjonalną, ciemną, meoniczną wol-

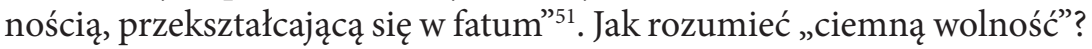
Jest ona związana z nicością, czymś, co poprzedza byt, co jest uprzednie wobec porządku i ładu, które są związane ze stworzeniem. Nie sposób jej doświadczyć, nie należy ona do porządku świata naturalnego. W szczególnego rodzaju doświadczeniu duchowym ukazuje się jako niczym nieuzasadniona, niemająca nie tylko związku z bytem, ale również ze światem i Bogiem. Gdyby pochodziła od Boga albo była zawarta w bycie, wówczas nie moglibyśmy wyjść poza predestynację. Wolność jest zatem nicością, czymś, z czego świat zostaje stworzony ${ }^{52}$. Jest czystą potencją i z niej „wychodzi zgoda na samo stworzenie, rozlega się z ta-

Tamże, s. 276.

Por. M. Bierdiajew, Głosze wolność..., dz. cyt., s. 53-55. 
jemniczej istoty potencji” ${ }^{3}$. Z tej „ciemnej wolności” rodzi się wolność rozumna, zakorzeniona w prawdzie, będąca celem życia, otrzymana od Boga, umożliwiająca twórczość. Jest „wyższą i ostateczną wolnością, autentycznym wyzwoleniem człowieka i świata" ${ }^{\prime 4}$.

Powiedzieliśmy za rosyjskim filozofem, że piekło to ciemna wolność przekształcająca się w fatum. Zatem piekło jest tam, gdzie człowiek albo nie wypracował w sobie zdolności do posiadania wolności rozumnej, albo też zdolność tę utracił. Biorąc pod uwagę całość myśli Bierdiajewa, wolno sądzić, że raczej ta druga możliwość wydaje się pełnym ujęciem piekła. Wolność złych jest pozostawaniem w sferze niebytu i ciemności, jest odrzuceniem raju: „ciemna wolność odrzucająca łaskę może nie zechcieć raju, może woleć piekło. Ci, którzy buntują się przeciwko idei piekła, nierzadko też sami wolą piekło. W ten sposób wolne przedkładanie piekła nad raj okazuje się fatum ciążącym nad stworzeniem" ${ }^{55}$.

Utrata możliwości twórczych, porzucenie wolności rozumnej nie dokonują się bez wiedzy Boga, zakładając, rzecz jasna, Jego wszechwiedzę. Mało tego, wolność jako taka, rozumiana jako możliwość dokonywania wyborów, okazuje się być fatalna, skoro umożliwia wolne odwrócenie się od niej samej. Stan ten wydaje się niemożliwy do przezwyciężenia. Nie potrafimy go wyjaśnić ani usprawiedliwić. Jest jakąś pierwotną daną, czymś, co zastajemy, co uprzedza każdorazowo nasze bytowanie. "Idea piekła jest ideą fatum na wieczność"56.

\section{Groza piekła}

Jak widać, różnica pomiędzy tradycyjnym pojmowaniem piekła a tym, jakie proponuje Bierdiajew, ma charakter zasadniczy. Jedno pozostaje niezmienne: piekło musi nieść ze sobą powiew grozy, pozostaje czymś, co napawa strachem. Inne jest jednak źródło lęku. U rosyjskiego

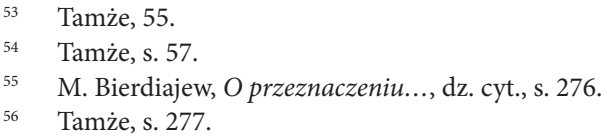


filozofa nie ma on obiektywnego charakteru, nie jest wywołany działaniem czynników zewnętrznych (mściwego Boga czy kuszącego Szatana) ${ }^{57}$. Źródło musi być umiejscowione w subiektywnym świecie, w zamknięciu, odgrodzeniu od jakiejkolwiek zewnętrzności. Piekło to nic innego, jak stan duszy zamkniętej w sobie. Ma charakter złej i ciemnej samotności, jest „męczącą chwilą" ${ }^{58}$, w której otwiera się „bezdeń i nieskończonośćn ${ }^{59}$. Przeżywana chwila staje się nieskończonością, czymś, co nigdy nie osiągnie kresu. Samotność ma charakter radykalny, jest ostatecznym pozostawaniem ze sobą, oddzieleniem „od Boga, od świata Bożego, od innych ludzi”"60. Bierdiajew wypowiada myśl o znaczeniu kluczowym: „piekło nie jest działaniem Boga na duszę, w danym wypadku sądowym i karnym, a jest właśnie nieobecnością działania Boga na duszę, niezdolnością duszy do otwarcia się na jakiekolwiek by nie było działanie Boga, jest całkowitym odpadnięciem od Boga. Piekło nie jest niczym innym, jak całkowitym oddzieleniem od Boga" ${ }^{\text {11. }}$

Samotność nie jest, jak można sądzić, wyłącznie stanem odgrodzenia od czynników zewnętrznych, doświadczeniem wewnętrznego opuszczenia. Jest rezultatem „grzesznego istnienia”'2 , przy czym rozumienie grzechu jest tu inne od tradycyjnego ujęcia. Ujmowanie go jako przestępstwa, w którym grzesznik poprzez swój czyn narusza wolę Boga, ma w sobie „coś niewolniczego"63. Działa tu prosty schemat winy i kary, odstępstwa i zadośćuczynienia. Tymczasem „grzech jest

57 Wnikliwą analizę tego tematu przeprowadza Wacław Hryniewicz. Pisze on, że atmosfera lęku wobec piekła rodziła się w historii jako następstwo tzw. lęków zbiorowych, powstałych na skutek klęsk, chorób czy wojen. Zastąpiono je „lękami teologicznymi” przed „grzechem, szatanem, Antychrystem, sądem, piekłem. Tak rodziła się pedagogia strachu, nieoddzielna od eschatologii o charakterze penitencjarnym. Chrześcijanin żył w atmosferze oblężenia, lęku przed sobą, szatanem i piekłem. W obliczu tylu zagrożeń łatwo już popaść w pokusę zwątpienia i rozpaczy, zachwiać się psychicznie i załamać" (W. Hryniewicz, Nadzieja..., dz. cyt., s. 21).

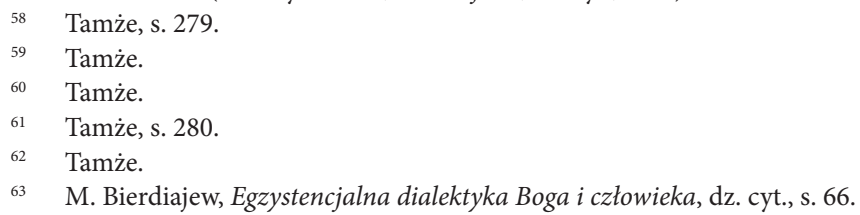


rozdwojeniem, brakiem, brakiem pełni, rozbiciem, zniewoleniem, nienawiścią, a nie nieposłuszeństwem i nie jest formalnym naruszeniem woli Bożej" ${ }^{64}$. Skoro tak, doprowadza on do stanu permanentnego zamknięcia, zerwania więzi ze wszystkim, co jest poza mną. Istotne nie jest to, że za konkretny czyn ponoszę wieczne konsekwencje, ale samo zniewolenie jako takie, pozostawanie $\mathrm{z}$ samym sobą, zamknięcie na jakąkolwiek ingerencję Boga ${ }^{65}$. Diabeł, zauważmy, nie jest kimś zewnętrznym wobec "ja" - to skazanie na przebywanie $\mathrm{z}$ samym sobą, zwierciadło, w którym zmuszam siebie do ciągłego oglądania własnego oblicza. Sąd boski zostaje zastąpiony samosądem, w którym wydaję na siebie wyrok nieustannego postrzegania i przeżywania popełnionej winy. Jest to „piekielna męka, męka sumienia" ${ }^{6}$. Zauważmy jeden jeszcze wymiar grozy piekła. Będzie ono wejściem w stan absolutnej beznadziejności, przeżywanej „całkowicie subiektywnie” ${ }^{67}$. Ma charakter na wskroś czasowy, nieustający.

\section{Piekło dla siebie. Piekło dla innych}

Wieczność jest radykalnym przekroczeniem czasowości. Przekonanie to, po wielekroć powtarzane przez Bierdiajewa, ma istotne konsekwencje. Jeśli piekło może mieć wyłącznie czasowy charakter, to sąd boski będzie również osądzeniem piekła; czasowe piekło będzie sądzone z perspektywy aczasowej. Wymierzenie sprawiedliwości ma miejsce „poza” naszą moralnością albo niezależnie od naszych osądów moralnych. „Sąd Boży znajduje się po tamtej stronie naszego rozróżniania dobra i zła, jest sądem po tamtej stronie" ${ }^{68}$. Oznacza to, że nikt z ludzi nie może dokonywać ostatecznych rozstrzygnięć co do tego, czy ktoś, w imię sprawiedliwości, zasługuje na wieczne potępienie. Jedyna możliwość to przyjęcie piekła dla samego siebie, radykalne i ostateczne

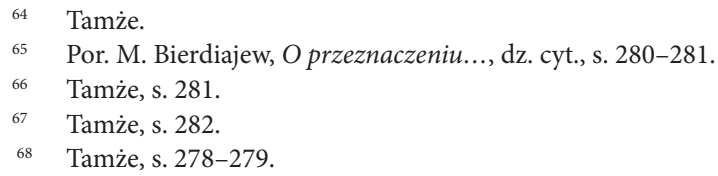


odseparowanie się od działania boskiego. Nie ma więc wyjścia poza subiektywny wymiar piekła. „Mogę przeżywać męki piekielne i uznawać siebie za zasługującego na męki piekielne. Nie można jednak pozwolić na piekło dla innych, nie można pogodzić się z piekłem dla innych. Wynika to już z tego, że piekła nie można obiektywizować i przedstawiać jako obiektywny porządek bytu"69.

Wątek ten wydaje się szczególnie doniosły w analizach rosyjskiego filozofa. Kiedy czytamy słowa: „Gdyby ludzie byli moralnie bardziej wrażliwi, to całe nastawienie swojej woli moralnej i swojego ducha skierowaliby na wybawienie $\mathrm{z}$ mąk piekielnych każdej istoty spotkanej przez nich w życiu"70, ujawnia się przed nami ktoś, komu nie są obce delikatność, a nawet subtelność ducha. Zasadniczym celem naszego życia jest zabieganie o to, by nikt nie był narażony na piekło uprzedmiotowione, ale też by nikt nie popadł w opisywaną wyżej sytuację zamknięcia w sobie. Należy zatem zaprzestać dzielenia ludzi na „dobrych” i „złych”. Zadanie tych pierwszych polega na tym, by za wszelką cenę chcieli zbawienia dla tych, którzy z racji popełnionych czynów są ponoć skazani na potępienie. Nie jest możliwe osiągnąć je samemu. Jeżeli czynię dobro, licząc na otrzymanie nagrody, zaprzeczam idei zbawienia. Zapominając o wiecznym losie innych ludzi, a szczególnie tych, których uważam za złych, urzeczywistniając raj tylko dla samego siebie, sprawiam, że będzie on dla mnie, tak naprawdę, nieosiągalny. „Raj nie jest dla mnie możliwy, jeśli moi bliscy, moi krewni lub nawet po prostu ludzie, z którymi wypadało mi być razem w życiu, będą w piekle"71. Słowa te mają doniosłe znaczenie. Raj przeznaczony wyłącznie dla mnie nie jest możliwy, jeśli dopuszczam, że w piekle są "heretyk” Jakob Boehme, „antychryst” Fryderyk Nietzsche, „poganin” Johann Wolfgang Goethe, "grzeszny” Aleksander Puszkin, czy wreszcie „niechrześcijanin” Arystoteles, którego uważa się za protoplastę filozofii i teologii ${ }^{72}$. Skoro zawdzięczam

\footnotetext{
69 Tamże, s. 279.

Tamże.

Tamże.

Por. tamże.
} 
im pewne dobro, które dzięki nim stało się również moim udziałem, to trzeba wziąć na siebie część ich męki, grzechu, czy mówiąc wprost, zła. Moim zadaniem moralnym jest wydostanie ich z piekła. Wątek ten wieńczy Bierdiajew poruszającym i niewymagającym komentarza zdaniem: „Świadomość moralna zaczęła się od Bożego pytania: «Kainie, gdzie jest twój brat Abel?». Zakończy się ona innym Bożym pytaniem: "Ablu, gdzie jest twój brat Kain?»"73.

\section{Piekło istnieje?}

Refleksje Bierdiajewa pokazują wyraźnie, że tak niefilozoficzny temat, jakim jest piekło, może prowadzić do inspirujących i głęboko etycznych wniosków. Nie należy popadać w uproszczenia, twierdząc, że prowadzone analizy zmierzają wyłącznie do tego, by udowodnić, że piekło nie istnieje. Rosyjski filozof nie staje jednoznacznie po stronie myślicieli opowiadających się za powszechnością zbawienia. Piekło jest tajemnicą, która uparcie wymyka się próbom racjonalizacji, jednak nie znaczy to, że nie jesteśmy w stanie rzetelnie o nim myśleć. Jeśli w kwestie eschatologiczne zaangażowany zostanie rozum, prędzej czy później popadniemy w trudności nie do pokonania. „Wszystkie racjonalne eschatologie są koszmarne. Koszmarna jest idea wiecznych mąk piekielnych, koszmarna jest idea nieskończonych reinkarnacji, koszmarna jest idea zniknięcia osoby w bycie Boskim, koszmarna jest nawet idea nieuchronnego powszechnego zbawienia"74. Pozostaje zatem wiara w ostateczne przezwyciężenie piekła. Ma ona ugruntowanie w osobie Bogoczłowieka - Chrystusa, w fakcie Jego zstąpienia do piekła, w sferę zaciemnionej wolności, radykalnego zamknięcia w sobie. Piekło nie jest „ostatnim” słowem, które Bóg wypowiada pod adresem człowieka. Jest ono słowem „przedostatnim” i może zostać zastąpione aktem zbawienia o definitywnym charakterze.

73 Tamże.

74 Tamże, s. 285. 
Warto odnotować kilka wniosków. Przede wszystkim sam Bierdiajew, który podejmuje polemikę z manicheizmem, nie do końca wydaje się wolny od jego wpływów. Zaciemniona wolność jest przebywaniem w sferze nicości, gdzie sam Bóg nie ma dostępu, a Jego wszechmoc, w zdumiewający sposób, pozostaje bezradna. Stąd wniosek, że piekło jako takie, będące pogrążeniem się w „meonicznej wolności”, nie jest wyłącznie wymysłem, fantasmagorią. Jest ono przeżywane przez człowieka w nim samym. Paradoks polega na tym, że ma ono charakter całkowicie subiektywny, choć dla tego, kto go doświadcza, jest do końca realne, obiektywne. Być może więc zmieniają się tylko rodzaje doznawanych mąk, inni są sprawcy cierpień, wreszcie odmienna jest piekielna sceneria. Jednak nie zmienia się nic prócz tego. Kto wie, może subiektywnie przeżywane piekło jest jeszcze bardziej tragiczne i przerażające, skoro doświadcza się go w totalnej samotności?

O piekle możemy rozprawiać wyłącznie z punktu widzenia nas samych, jako istot żyjących i podatnych na upływ czasu. Czymś niezwykle cennym jest polemika rosyjskiego filozofa $z$ tradycyjnym pojmowaniem piekła. Nie ulega bowiem wątpliwości, że wizja miejsca, w którym źli ponoszą zasłużoną karę za popełnione czyny, wciąż istnieje w świadomości ludzi. Tymczasem okazuje się, że być może piekło obecne jest już na ziemi i „dzieje się” we mnie samym. Dostrzec tu można znaczącą różnicę pomiędzy tym, co mówi Bierdiajew, a słynnym zdaniem Sartre’a z dramatu Przy drzwiach zamkniętych. Kiedy Garcin wypowiada słowa: "Żadnych palenisk nie trzeba. Piekło to są inni”, wyraża całe swoje udręczenie obecnością przy nim drugiej osoby, świadka jego grzesznego czynu. Piekło jest tutaj milczącą obecnością obserwatora, dławiącą mocą spojrzenia, od którego nie sposób się uwolnić. U Bierdiajewa człowiek w piekle patrzy na siebie i sam siebie dręczy. Jeśli przyznać rację twierdzeniom, że piekło ma swoje miejsce raczej na ziemi, a nie w wymiarach wieczności, obydwie te koncepcje zdają się jednak uzupełniać. Popełniona wina, moralne zło jest nie tylko moim aktem, dokonanym przeze mnie. Jest również odbiorca owego aktu, ktoś, komu została wyrządzona krzywda. Odczuwany przez niego ból będzie oskarżeniem równie dotkliwym jak wyrzut sumienia. To dlatego właśnie problem piekła jawi 
się jako centralne zagadnienie etyki. Jeśli nie podejmie się prób jego rozwiązania, pozostanie ona niepełna i ułomna. Wkładem Bierdiajewa do dyskusji o piekle jest uwrażliwienie na etykę i jej znaczenie dla naszego życia, jak również na mistykę i jej rolę w filozoficznym myśleniu. Okazuje się, że piekło ma również ten właśnie, mistyczny wymiar.

Otwarte pozostaje pytanie, czy piekło jest jakoś „zasiedlone”, czy też stanowi wyłącznie przestrogę, nigdy do końca niezrealizowaną. Rosyjski filozof wykazuje tu umiarkowany optymizm, przynajmniej o tyle, o ile umiejscawiamy piekło w zaświatach, w których Bóg odnosi ostateczne i nieodwołalne zwycięstwo. Kto wie jednak, czy wizja piekła przeżywanego w czasie, o której tyle opowiada, nie jest jeszcze bardziej zatrważająca i, niestety, możliwa? 